\title{
Isolation of a New Free-living Bacterium Containing R-bodies
}

\author{
By M. C. FUSTÉ,* M. D. SIMON-PUJOL, A. M. MARQUÉS, J. GUINEA \\ AND F. CONGREGADO \\ Departamento de Microbiología, Facultad de Farmacia, Zona Universitaria de Pedralbes, \\ 08028-Barcelona, Spain
}

(Received 14 May 1986)

Strain EPS-5028 is a free-living bacterium which contains R-bodies. By its morphology, biochemical characteristics and $\mathrm{G}+\mathrm{C}$ content, strain EPS-5028 differs from the other known free-living R-body-containing bacteria, Pseudomonas avenae and Pseudomonas taeniospiralis. Phage and particles resembling phage heads were observed in cells induced with UV irradiation.

\section{INTRODUCTION}

$\mathrm{R}$-bodies are refractile inclusions that are unique in nature. In its compact form an $\mathrm{R}$-body is a long ribbon of protein wound into a tight roll, but it can also unroll into a long twisted filament. It is of taxonomic importance because it is the morphological characteristic which permits the genus Caedibacter to be distinguished from other bacterial endosymbionts of ciliates (Preer \& Preer, 1984). Lalucat $e$ al (1978) were the first to describe R-bodies in a free-living bacterium: a new species of hydrogen-oxidizing bacterium, Pseudomonas taeniospiralis. R-bodies were subsequently reported in Pseudomonas avenae (Wells \& Horne, 1983). R-bodies are presumably coded by a defective prophage, whose spontaneous induction determines the production of defective phages and R-bodies (Dilts, 1977). This group of bacteriophages, occurring in different groups of bacteria (Lalucat et al., 1979), may have a common origin or may have arisen by convergent evolution. This report describes the isolation of an R-body-containing, nitrogenscavenging bacterium which is different from $P$. avenae and $P$. taeniospiralis.

\section{METHODS}

Organism and growth. After screening extracellular polysaccharide-producing micro-organisms, bacterial strain EPS-5028 was isolated from a soil sample collected in Barcelona (Spain). Appropriate dilutions of the sample were inoculated on plates of tryptone soya agar (Oxoid) (TSA) and incubated at $30^{\circ} \mathrm{C}$. After $72 \mathrm{~h}$ incubation, colonies of mucoid appearance were picked, streaked onto fresh TSA plates and incubated for $72 \mathrm{~h}$ at $30^{\circ} \mathrm{C}$. Viscous-looking colonies were restreaked onto TSA slants and stored at $4^{\circ} \mathrm{C}$. Strain EPS-5028 was the most mucoid and was selected for our preliminary experiments (Congregado et al., 1985).

Pseudomonas taeniospiralis DSM 2082 was used as a reference strain from nutritional characterization and DNA studies. Azospirillum brasilense ATCC 29145 and Azotobacter vinelandii A TCC 9140 were used as reference strains for nitrogen-fixation studies.

The modified mineral salts medium of Patt $e t$ al. (1974) was used for most experiments. The autoclaved basal salts medium was supplemented with filter-sterilized glucose to a final concentration of $0.5 \%$. The pH was adjusted to 7 with $1 \mathrm{M}-\mathrm{NaOH}$ as required. Difco Noble agar $(1 \%, \mathrm{w} / \mathrm{v})$ was used to solidify the medium as necessary. Flasks containing $100 \mathrm{ml}$ medium were inoculated with $0.1 \mathrm{ml}$ of a cell suspension which had been washed three times with sterile phosphate buffer $(\mathrm{pH} 7)$ and adjusted to an $\mathrm{OD}_{520}$ of about $0 \cdot 2$, and incubated aerobically at $30^{\circ} \mathrm{C}$ for $72 \mathrm{~h}$ with shaking. Growth was measured as $\mathrm{OD}_{520}$. For growth studies, cells were cultivated in a 10-1 Braun Biostat $\mathrm{S}$ fermenter operating at $25{ }^{\circ} \mathrm{C}$ (impeller speed, 500 r.p.m.; pH 7; 80-100\% $\mathrm{O}_{2}$ saturation) containing 71 mineral salts medium (with or without a source of combined nitrogen). 
The ability of the isolate to grow in the absence of combined nitrogen was tested with a liquid nitrogen-free medium (Becking, 1981). Nitrogen fixation was estimated by the acetylene-reduction technique (Postgate, 1972), by measuring the ethylene production of cultures $(5 \mathrm{ml})$ in $18 \mathrm{ml}$ vials at $30^{\circ} \mathrm{C}$ in both $\mathrm{N}$-free liquid and semisolid medium. A loopful of bacteria from a previous $48 \mathrm{~h}$ culture was used as inoculum for each vial. After 24,48 and $72 \mathrm{~h}$, vials were closed with serum stoppers, and $0.2 \mathrm{ml} \mathrm{C}_{2} \mathrm{H}_{2}$ was injected into each vial. The amount of ethylene produced was determined after 1,24 and $72 \mathrm{~h}$ by gas chromatography with a Perkin-Elmer model F-33 gas chromatograph equipped with a flame-ionization detector and operated at a column temperature of $50{ }^{\circ} \mathrm{C}$. The carrier gas flow rate was $25 \mathrm{ml} \mathrm{N}_{2} \mathrm{~min}^{-1}$ in a column $(0.32 \times 50 \mathrm{~cm})$ packed with $80-100$ mesh Porapak N. Vials inoculated with Azotobacter vinelandii, Azospirillum brasilense, and heat-killed cultures were used as controls. Six replicate cultures were tested for each strain.

The media and conditions used for autotrophic growth were as given by Lalucat et al. (1979). The cells were cultivated autotrophically at $30^{\circ} \mathrm{C}$ in $1-1$ Erlenmeyer flasks containing $100 \mathrm{ml}$ mineral medium incubated in desiccators under an atmosphere of $\mathrm{O}_{2} / \mathrm{CO}_{2} / \mathrm{H}_{2}(1: 1: 8$, by vol.) with stirring. $P$. taeniospiralis was used as control. Three replicate cultures were tested for each strain.

Characterization. Phenotypic characterization was performed according to Cowan (1974). The $\mathrm{G}+\mathrm{C}$ content of DNA was measured by the thermal denaturation method (Mandel \& Marmur, 1968).

Electron microscopy. For negative staining a drop of the sample was applied to a copper grid coated with Formvar and carbon and stained with $2 \%(\mathrm{v} / \mathrm{v})$ phosphotungstic acid $(\mathrm{pH} 7)$ or $4 \%(\mathrm{w} / \mathrm{v})$ uranyl acetate $(\mathrm{pH} 4.8)$. Unstained samples were also examined. Drops of broth culture were placed onto carbon-stabilized Formvar films on 300 mesh copper grids and the specimens shadowed with platinum. For thin sections, preparations were fixed in $3 \%(\mathrm{w} / \mathrm{v})$ glutaraldehyde in $0 \cdot 1 \mathrm{~m}$-sodium phosphate buffer $(\mathrm{pH} 7 \cdot 2)$, treated with $1 \%(\mathrm{w} / \mathrm{v})$ osmium tetroxide, dehydrated and embedded in Spurr resin, sectioned on a LKB Ultratome UM III ultramicrotome and double stained with uranyl acetate and lead citrate. The grids were examined in a Philips EM 301 electron microscope at an operating voltage of $80 \mathrm{kV}$.

Mitomycin C treatment and $U V$ irradiation. Mitomycin $\mathrm{C}\left(0 \cdot 1 \mathrm{mg} \mathrm{ml}^{-1}\right)$ was added to $10 \mathrm{ml}$ cultures growing exponentially in mineral medium supplemented with sodium gluconate $(0 \cdot 25 \%)$ according to Lalucat et al. (1979). Cultures were irradiated for $90 \mathrm{~s}$ at a distance of $40 \mathrm{~cm}$ from a $15 \mathrm{~W}$ germicidal Philips lamp providing $253 \mathrm{~nm} \mathrm{UV}$ light (Preer et al., 1974). The irradiated cells were then incubated under the conditions described above.

Preparation of $R$-bodies. R-bodies for electron microscopy were prepared as described by Wells \& Horne (1983). The resulting pellet was resuspended in $50 \mathrm{~mm}$-phosphate buffer ( $\mathrm{pH} \mathrm{7)}$.

\section{RESULTS AND DISCUSSION}

Exponentially growing cells of strain EPS-5028 in liquid medium were rod-shaped (length $1 \cdot 3-2 \mu \mathrm{m}$, width $0 \cdot 8-1 \mu \mathrm{m}$ : Fig. $1 a$ ). During the stationary phase coccoid forms occasionally appeared. The Gram reaction was negative and the cell wall structure indicated a typical Gramnegative organization. Two polar flagella were observed (Fig. $1 a$ ) and cells were motile during the early phase of growth. Small pale colonies surrounded by abundant slime were formed on solid medium.

Transmission electron microscopy of cultures in several growth phases revealed R-bodies, normally one per cell (Fig. $1 b-d$ ). Phages or phage-like particles were not observed; they were found after UV treatment (Fig. $1 e$ ) but not after incubation with mitomycin $\mathrm{C}$.

The production of one R-body has been shown to be determined by DNA sequences on a plasmid (Quackenbush \& Burbach, 1983) and perhaps by phage or chromosomal genes in other bacteria (Quackenbush, 1978). Close genetic relationships between bacteria do not seem to be necessary for production of R-bodies. This is not altogether surprising, given that these structures are determined by nucleotide sequences in plasmids or phages or a small percentage of the nuclear DNA (Gibson, 1984). This had led to the suggestion that R-body formation occurs in different groups of bacteria. The presence of R-bodies in EPS-5028 supports this hypothesis because our strain is quite different from Pseudomonas avenae and $P$. taeniospiralis.

Table 1 lists the characters which differentiate EPS-5028 from other R-body-containing bacteria. The phenotypic and genetic characters of $P$. avenae were gathered from the literature. The DNA G $+C$ contents of $P$. avenae $(70.2 \mathrm{~mol} \%)$ and $P$. taeniospiralis $(60.4 \mathrm{~mol} \%)$ are different from our isolate $(65.1 \mathrm{~mol} \%)$. There are several consistent differences between EPS5028 and $P$. avenae and $P$. taeniospiralis, and on the basis of these distinct properties strain EPS5028 cannot be assigned to either of these species. 

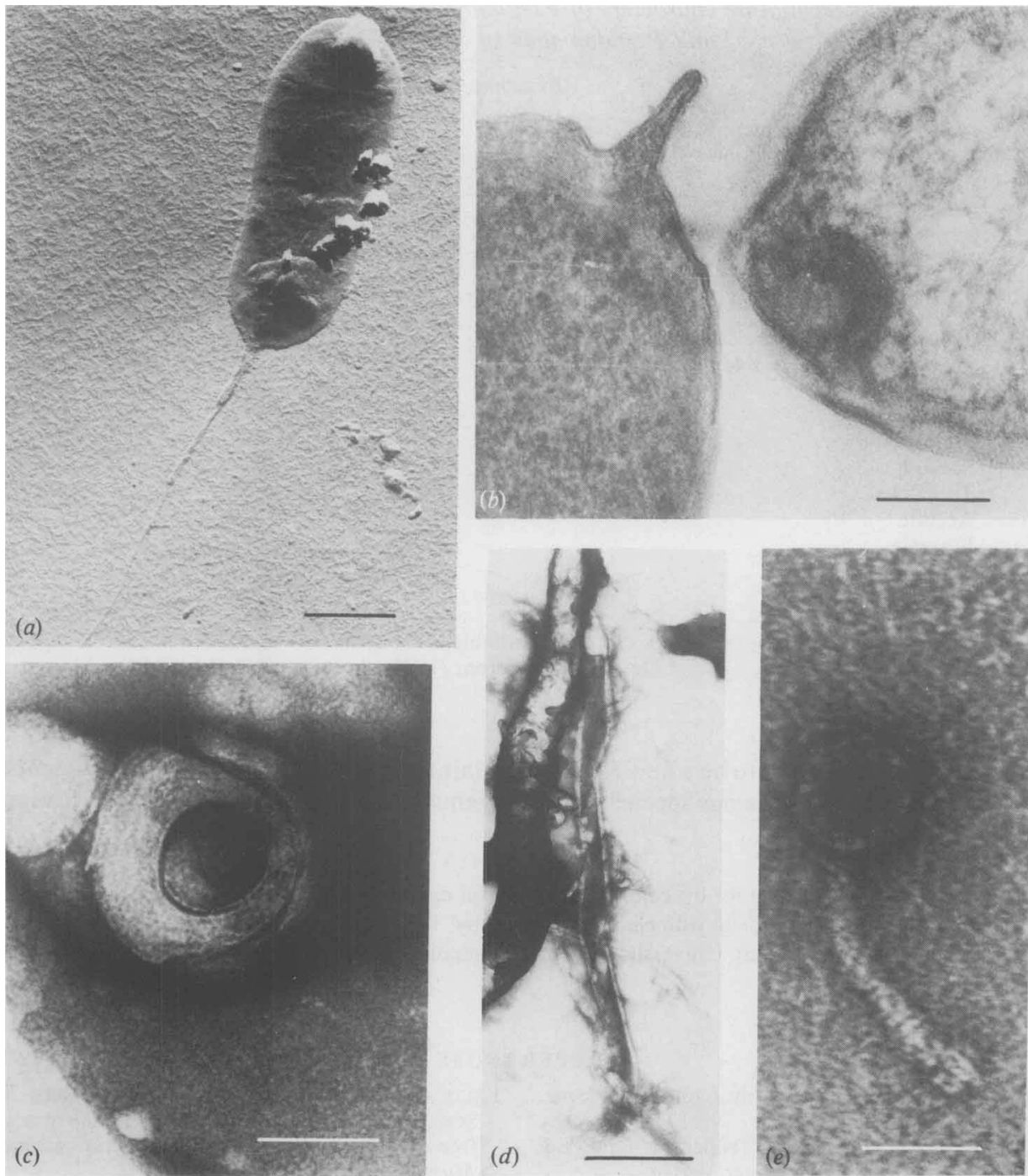

Fig. 1. Electron micrographs of: (a) EPS-5028; (b) thin section of EPS-5028 containing an R-body; (c) an intact, coiled R-body; $(d)$ an unrolled R-body; $(e)$ phage from EPS-5028. Bar markers represent: $(a)$ $0.5 \mu \mathrm{m},($ b) $1 \mu \mathrm{m},(c) 0.1 \mu \mathrm{m},(d) 0.4 \mu \mathrm{m},(e) 50 \mathrm{~nm}$.

In addition to differences in seven biochemical properties and $G+C$ content, EPS-5028 may be distinguished from other R-body-containing bacteria by its apparent ability to grow in the absence of combined nitrogen. The growth rate with inorganic nitrogen and glucose $\left(0.344 \mathrm{~h}^{-1}\right)$ was higher than that with glucose-containing, nitrogen-free medium $\left(0.197 \mathrm{~h}^{-1}\right)$. Nitrogenase activity was not detected in liquid or semisolid nitrogen-deficient glucose medium. In this respect EPS-5028 resembles Pseudomonas glathei (Palleroni, 1984); but it can be distinguished from $P$. glathei in being positive for arginine dihydrolase, lactose and disaccharide utilization, and in its failure to grow on oxalate and on acid media. 
Table 1. Some differentiating characters of Pseudomonas taeniospiralis, Pseudomonas avenae and Pseudomonas sp. EPS-5028

Test

Aerobic autotrophic growth with $\mathrm{H}_{2}$

Heterotrophic denitrification

Oxidase

Urease

Hydrolysis of gelatin

Hydrolysis of starch

Production of acids from

carbohydrates

Poly- $\beta$-hydroxybutyric acid

Compounds serving as sole

carbon source:

Arabinose

Maltose

Sorbose

Trehalose

Acetate

Butyrate

Citrate

Isoleucine
$P$. taeniospiralis

P. avenae*

ND

+
+
+
+
+
+
+
+
+
+

ND, No data available

* Data from Palleroni (1984).
EPS-5028

$\begin{array}{ll}\text { ND } & - \\ - & - \\ - & + \\ \text { ND } & + \\ + & - \\ + & - \\ + & + \\ + & - \\ & \\ - & + \\ - & + \\ + & + \\ - & + \\ \text { ND } & + \\ \text { ND } & + \\ \text { ND } & + \\ \text { ND } & +\end{array}$

Strain EPS-5028 appears to be a new R-body-containing bacterium and it cannot be identified with any described Pseudomonas species. Its exact genus and species status is being investigated in our laboratory.

We thank Professor J. Lalucat for his comments and useful discussions during the course of this work and J. Blavia and R. Bargallo for their help with electron microscopy. This work was supported in part by grants from Direcció General d'Ensenyament Universitari of the Generalitat de Catalunya and the Comisión Asesora Cientifica y Técnica.

\section{REFERENCES}

BECKING, J. H. (1981). The family Azotobacteraceae. In The Prokaryotes, vol. 1, pp. 795-817. Edited by M. P. Starr, H. Stolp, H. G. Trüper, A. Balows \& H. G. Schlegel. Berlin: Springer Verlag.

Congregado, F., Estañol, I., Espuny, M. J., Fusté, M. C., Manresa, M. A., Marques, A. M., Guinea, J. \& Simon-Pujol, M. D. (1985). Preliminary studies on the production and composition of the extracellular polysaccharide synthesized by Pseudomonas sp. EPS-5028. Biotechnology Letters 7, 883-888.

Cowan, S. T. (1974). Cowan and Steel's Manual for the Identification of Medical Bacteria. Cambridge: Cambridge University Press.

Dilts, J. A. (1977). Chromosomal and extrachromosomal deoxyribonucleic acid from four bacterial endosymbionts derived from stock 51 of Paramecium tetraurelia. Journal of Bacteriology 129, 885-894.

GiBSON, I. (1984). A comparison of the refractile bodies (R-bodies) of certain bacteria. III. Nucleotide sequence homologies and R-body function. Micron and Microscopica acta 15, 253-259.

LALuCAT, J. \& MAYER, F. (1978). 'Spiral bodies' intracytoplasmic membraneous structures in a hydrogen oxidizing bacterium. Zeitschrift für allgemeine Mikrobiologie 18, 517-521.
Lalucat, J., Meyer, O., Mayer, F., Pares, R. \& SCHLEGEL, H. G. (1979). R-bodies in newly isolated free-living hydrogen-oxidizing bacteria. Archives of Microbiology 121, 9-15.

MANDEL, M. \& MARMUR, J. (1968). Use of ultraviolet absorbance-temperature profile for determining the guanine plus cytosine content of DNA. Methods in Enzymology 12B, 195-206.

Palleroni, N. J. (1984). Pseudomonas. In Bergey's Manual of Systematic Bacteriology, vol. 1, pp. 141199. Edited by N. R. Krieg. Baltimore: Williams \& Wilkins.

Patt, T. E., Cole, G. C., Bland, J. \& Hanson, R. S. (1974). Isolation and characterization of bacteria that grow on methane and organic compounds as sole sources of carbon and energy. Journal of Bacteriology 120, 955-964.

Postgate, J. R. (1972). The acetylene reduction test for nitrogen fixation. Methods in Microbiology 6B, 343356.

Preer, J. R. \& Preer, L. B. (1984). Endosymbionts. In Bergey's Manual of Systematic Bacteriology, vol. 1, pp. 795-811. Edited by N. R. Krieg. Baltimore: Williams \& Wilkins.

Preer, J. R., Preer, L. B. \& Jurand, A. (1974). 
Kappa and other endosymbionts in Paramecium aurelia. Bacteriological Reviews 38, 113-163.

QUACKenBuSH, R. L. (1978). Genetic relationships among bacterial endosymbionts of Paramecium aurelia: deoxyribonucleotide sequence relationships among members of Caedibacter. Journal of General Microbiology 108, 181-187.

QuaCKEnbush, R. L. \& BURBaCh, J. A. (1983). Cloning and expression of DNA sequences associated with the killer trait of Paramecium tetraurelia stock 47. Proceedings of the National Academy of Sciences of the United States of America 80, 250-254.

WELlS, B. \& HoRne, R. W. (1983). The ultrastructure of Pseudomonas avenae. II. Intracellular refractile ( $\mathrm{R}$ body) structure. Micron and Microscopica acta 14, 329-344. 